\title{
Anti-inflammatory and analgesic activities of methanol extract of Helianthus annuus Linn. (Asteraceae) leaf
}

\author{
Samuel O. Onoja ${ }^{1 *}$, Glory C. Onyebuchi² ${ }^{2}$ Ifeoma I. Ijeh² and Maxwell I. Ezeja ${ }^{1}$
}

\begin{abstract}
This study evaluate the anti-inflammatory and analgesic properties of Helianthus annuus Linn. in rats. Methanol extract of Helianthus annuus (HAE) leaf was used in this study. Formalin- and egg-albumin induced-paw edema were used to investigate the anti-inflammatory activities while acetic acid-induced writhing reflex and tail flick models were used to evaluate the analgesic properties. The doses of HAE used were 150,300 and $600 \mathrm{mg} / \mathrm{kg}$. Acetylsalicylic acid (ASA) was used as reference drug in the anti-inflammatory and writhing reflex models while pentazocine (reference drug) was used in tail flick model. The negative control was dosed $5 \%$ tween-20 $(10 \mathrm{ml} / \mathrm{kg})$. The HAE exhibited significant $(\mathrm{P}<0.05)$ dose-dependent anti-inflammatory and analgesic activities. At 3 hour (h) post treatment, the HAE (300 $\mathrm{mg} / \mathrm{kg}$ ) produced $33.33 \%$ and $32.94 \%$ while ASA produced $36.36 \%$ and $35.29 \%$ reduction in paw volume in the formalin and egg-albumin induced paw edema models respectively when compared with negative control. In the acetic acid-induced writhing reflex, ASA and HAE (600 mg/kg) produced 67.89\% and $35.78 \%$ reduction in the number of writhing, respectively when compared with the negative control. Pentazocine and HAE $(300 \mathrm{mg} / \mathrm{kg}$ ) caused $67.62 \%$ and $35.24 \%$ increase in pain reaction time when compared with the negative control. The study affirms the folkloric uses of Helianthus annuus in the management of pain and inflammation.
\end{abstract}

Keywords: Acetic acid, acetylsalicylic acid, analgesic, anti-inflammatory, Helianthus annuus

'Department of Veterinary Physiology and Pharmacology, College of Veterinary Medicine, Micheal Okpara University of Agriculture, PMB 7267, Umudike, Abia State, Nigeria,

${ }^{2}$ Department of Biochemistry, College of Natural Sciences, Micheal Okpara University of Agriculture, PMB 7267,

Umudike, Abia State, Nigeria

*Corresponding author: S. O. Onoja E-mail: onoja.samuel@mouau.edu.ng; samonreal@yahoo.com

DOI: 10.2478/ebtj-2019-0013

\section{Introduction}

Inflammation is an immunological reaction and implicated in the pathophysiology of many disease conditions $(1,2)$. Uncontrolled inflammatory reaction may aggravate pathological conditions and it is marked with pain, swelling, heat, redness and loss of function (3). Inflammatory processes are suppressed with anti-inflammatory drug in medical practice. Ethnomedical preparations improves clinical disease conditions by suppression of inflammatory processes (4-6). Helianthus annuus Linn. is one of the medicinal plants used in ethnomedical practice with suspected anti-inflammatory activity (7).

Helianthus annuus Linn. belong to the family Asteraceae. It has wide folkloric uses in the ethnomedical practice of South Eastern Nigeria, India and Pakistan (8). The plant is used in the treatment of pyrexia, inflammation, worm infestation, diabetes mellitus and other stomach problems (9). The phytochemical screening of the leaf have reported the presences of alkaloids, saponins, glycosides, terpenes, sterols, tannins and flavonoids (10, 11). Bioactive compounds such as Helivypolide G, annuionones a, b, c and helinorbisabone, 24a-Methyl-5 $\alpha$-cholest-7-en-3 3 -ol, Annuithrin, heliangolide, niveusin B and its ethoxy derivatives have been isolated from $H$. annuus $(12,13)$. There are literatures on the antidiabetic, antioxidant, antihepatotoxic, antimicrobial and antidiarrhoea activities of $H$. annuus $(8,14)$. The present study investigated the anti-inflammatory and analgesic properties of methanol extract of Helianthus annuus leaf in rat. 


\section{Materials and Methods}

\section{Plant collection and extract preparation}

The leaf of $H$. annuus (voucher number; MOUAU/ VPP/2015/16) was harvested from University of Nigeria Nsukka environment and identified by Mr. A.O. Ozioko. The leaves were air dried under shed and later ground into powder with manual grinder (Corona, China). Two hundred grams (200 g) of the powdered plant material were extracted using cold maceration method with $80 \%$ methanol, concentrated and the percentage yield was determined as described by Onoja et al. (15).

\section{Experimental animals}

One hundred and twenty (120) Wistar albino rats of both sexes weighing 100-115 grams were used for this experiment. The environmental condition of the animal house and other management practices were as explained by Onoja et al. (15). The experimental protocol was approved by the University Animal Ethics Committee with reference MOUAU/CVM/ EAEC/2015/010.

\section{Phytochemical analysis}

The presence of tannins, saponins, alkaloids, flavonoids, glycosides and terpenes were determined using standard methods of Trease and Evans (16).

\section{Anti-inflammatory study}

The in vivo anti-inflammatory activities of Helianthus annuus extract (HAE) was evaluated with formalin-and egg albumin-induced paw edema as described by Onoja et al. (15). Thirty rats were assigned to five groups $(n=6)$. Groups 1 and 2 received 5\% Tween-20 (10 ml/kg) (negative control) and acetylsalicylic acid (ASA) (200 mg/kg; positive control), respectively. Groups 3, 4 and 5 received HAE at dose range of 150, 300 and $600 \mathrm{mg} / \mathrm{kg}$, respectively. Volume displacement method was used in the determination of paw volumes.

\section{Analgesic study}

The antinociceptive properties of HAE was evaluated as described by Onoja et al. (15). Acetic acid-writhing reflex was employed in the evaluation of peripheral activity while tail flick test was adopted in the evaluation of central activity. The animal grouping and treatments were as stated in the anti-inflammatory study except that, ASA $(200 \mathrm{mg} / \mathrm{kg})$ was used as the positive control for the peripheral antinociceptive activity while pentazocine $(3 \mathrm{mg} / \mathrm{kg}$ ) was used as the positive control for the central antinociceptive activity.

\section{Data analysis}

The results were presented as mean \pm standard error of mean (SEM). Data obtained were analyzed using one way analysis of variance (ANOVAs) and the variant means were separated by Least Significant Difference (LSD) of the different groups. Significance was accepted at the level of $\mathrm{p}<0.05$.

\section{Results}

\section{Yield of the HAE}

The percentage yield of the HAE was $10.31 \%$.

\section{Phytochemical analysis}

The test revealed the presence of tannins, saponins, alkaloids, flavonoids, glycosides and terpenes.

\section{Formalin-induced paw edema}

The HAE elicited significant $(\mathrm{P}<0.05)$ decrease in the paw volume in the treated groups when compared with the negative control group. At $3 \mathrm{~h}$ post treatment, the reduction in paw volume of ASA, HAE 150, 300 and $600 \mathrm{mg} / \mathrm{kg}$ treated groups were $36.36 \%, 24.24 \%, 33.33 \%$ and $33.33 \%$ reduction in paw volume, respectively when related to the negative control. The percentage inhibition in paw volume of HAE (300 and $600 \mathrm{mg} /$ $\mathrm{kg})$ treated groups were not significant $(\mathrm{p}>0.05)$ compared to ASA treated group (Table 1).

\section{Egg albumin-induced paw edema}

At $3 \mathrm{~h}$ post treatment the ASA, HAE 150, 300 and $600 \mathrm{mg} / \mathrm{kg}$ caused $35.29 \%, 29.41 \%, 32.94 \%$ and $31.76 \%$ reduction in paw volume in treated rats, respectively when compared with the negative control. The percentage inhibition in paw volume of HAE (300 and $600 \mathrm{mg} / \mathrm{kg}$ ) treated groups were not significant ( $p>0.05$ ) compared to ASA treated group (Table 2).

Table 1. Formalin-induced paw edema

\begin{tabular}{|c|c|c|c|}
\hline \multirow{2}{*}{ Treatment $(n=6)$} & \multicolumn{3}{|c|}{ Mean increase in paw volume in $\mathrm{ml} \pm$ SEM (\% inhibition) } \\
\hline & $1 \mathrm{~h}$ & $2 \mathrm{~h}$ & $3 \mathrm{~h}$ \\
\hline $5 \%$ Tween-20, $10 \mathrm{ml} / \mathrm{kg}$ & $0.39 \pm 0.02(-)$ & $0.44 \pm 0.04(-)$ & $0.33 \pm 0.04(-)$ \\
\hline ASA $200 \mathrm{mg} / \mathrm{kg}$ & $0.27 \pm 0.02 *(30.77)$ & $0.21 \pm 0.02 *(52.27)$ & $0.21 \pm 0.01 *(36.36)$ \\
\hline $\mathrm{HAE} 150 \mathrm{mg} / \mathrm{kg}$ & $0.36 \pm 0.03(7.69)$ & $0.29 \pm 0.04 *(34.09)$ & $0.25 \pm 0.03 *(24.24)$ \\
\hline HAE 300 mg/kg & $0.28 \pm 0.03 *(28.21)$ & $0.24 \pm 0.05 *(45.45)$ & $0.22 \pm 0.05^{*}(33.33)$ \\
\hline HAE $600 \mathrm{mg} / \mathrm{kg}$ & $0.31 \pm 0.02 *(20.51)$ & $0.24 \pm 0.03 *(45.45)$ & $0.22 \pm 0.03 *(33.33)$ \\
\hline
\end{tabular}


Table 2. Egg albumin- induced paw edema

\begin{tabular}{|l|l|l|l|}
\multirow{2}{*}{ Treatment $(\boldsymbol{n}=6)$} & \multicolumn{3}{ll}{ Mean increase in paw volume in $\mathrm{ml} \pm \mathrm{SEM}(\%$ inhibition) } \\
\cline { 2 - 4 } & $1 \mathrm{~h}$ & $2 \mathrm{~h}$ & $3 \mathrm{~h}$ \\
\hline $5 \%$ Tween-20, $10 \mathrm{ml} / \mathrm{kg}$ & $0.85 \pm 0.07(-)$ & $0.83 \pm 0.08(-)$ & $0.85 \pm 0.05(-)$ \\
\hline ASA $200 \mathrm{mg} / \mathrm{kg}$ & $0.83 \pm 0.02(2.35)$ & $0.78 \pm 0.05(6.02)$ & $0.55 \pm 0.08 *(35.29)$ \\
\hline HAE $150 \mathrm{mg} / \mathrm{kg}$ & $0.93 \pm 0.01(-9.41)$ & $0.79 \pm 0.02(4.82)$ & $0.60 \pm 0.04 *(29.41)$ \\
\hline HAE $300 \mathrm{mg} / \mathrm{kg}$ & $0.50 \pm 0.03^{*}(41.17)$ & $0.78 \pm 0.06(6.02)$ & $0.57 \pm 0.09 *(32.94)$ \\
\hline HAE $600 \mathrm{mg} / \mathrm{kg}$ & $0.75 \pm 0.08(11.76)$ & $0.67 \pm 0.09(19.28)$ & $0.58 \pm 0.07 *(31.76)$
\end{tabular}

${ }^{*} p<0.05$ compared with 5\% Tween-20 treated group; HAE: Helianthus annuus extract, ASA: acetylsalicylic acid

Table 3. Acetic acid induced writhing test

\begin{tabular}{|l|l|l|}
\hline Treatment $(\boldsymbol{n}=\mathbf{6})$ & Mean writhing number & \% inhibition \\
\hline $5 \%$ Tween-20, $10 \mathrm{ml} / \mathrm{kg}$ & $21.80 \pm 0.48$ & - \\
\hline ASA $200 \mathrm{mg} / \mathrm{kg}$ & $7.00 \pm 0.58^{*}$ & 67.89 \\
\hline HAE $150 \mathrm{mg} / \mathrm{kg}$ & $19.80 \pm 0.87^{*}$ & 9.17 \\
\hline HAE $300 \mathrm{mg} / \mathrm{kg}$ & $17.60 \pm 0.66^{*}$ & 19.27 \\
\hline HAE $600 \mathrm{mg} / \mathrm{kg}$ & $14.00 \pm 0.58^{*}$ & 35.78 \\
\hline${ }^{*} \mathrm{p}<0.05 \mathrm{compared}$ with 5\% Tween-20 treated group; HAE: Helianthus annuus extract, ASA: acetylsalicylic acid \\
\hline
\end{tabular}

\section{Acetic acid induced writhing reflex}

The ASA and HAE 150, 300 and $600 \mathrm{mg} / \mathrm{kg}$ caused $67.89 \%$, $9.17 \%, 19.27 \%$ and $35.78 \%$ reduction in writhing reflex in treated groups, respectively when compared with the negative control group (Table 3 ).

\section{Tail flick test}

Pentazocine and (HAE 150, 300 and $600 \mathrm{mg} / \mathrm{kg}$ ) increased the PRT in treated rats by $67.62 \%, 19.05 \%, 35.24 \%$ and $22.86 \%$, respectively when compared with the negative control. The PRT of HAE treated groups were low $(\mathrm{p}<0.05)$ when compared to the pentazocine treated group (Table 4 ).

\section{Discussion}

The HAE reduced $(\mathrm{p}<0.05)$ paw edema induced with formalin and egg-albumin and reduced $(\mathrm{p}<0.05)$ writhing reflex in treated rat. It also increased the pain reaction time in treated rats. It produced potent anti-inflammatory and analgesic activities which might be linked to the phytoconstituents. Onoja and Anaga (17) reported the presence of flavonoids, Tannins, alkaloids and saponins in the methanol extract of $H$. annuus leaf which is also in agreement with the results of the present study. The anti-inflammatory and analgesic properties of these phytochemicals have been documented $(18,19)$. The choice of the doses used in this study was based on previous reports and

Table 4. Tail flick test

\begin{tabular}{|l|l|l|}
\hline Treatment $(\boldsymbol{n}=\mathbf{6})$ & PRT $(\mathrm{sec})$ & \% inhibition \\
\hline $5 \%$ tween-20, $10 \mathrm{ml} / \mathrm{kg}$ & $2.10 \pm 0.21$ & - \\
\hline Pentazocine $3 \mathrm{mg} / \mathrm{kg}$ & $3.52 \pm 0.41^{*}$ & 67.62 \\
\hline HAE $150 \mathrm{mg} / \mathrm{kg}$ & $2.50 \pm 0.08^{*}$ & 19.05 \\
\hline HAE $300 \mathrm{mg} / \mathrm{kg}$ & $2.84 \pm 0.24^{*}$ & 35.24 \\
\hline HAE $600 \mathrm{mg} / \mathrm{kg}$ & $2.58 \pm 0.15^{*}$ & 22.86 \\
\hline${ }^{*} \mathrm{p}<0.05 \mathrm{compared}$ with $5 \%$ Tween-20 treated group; HAE: Helianthus annuus extract, PRT: pain reaction time, SEC: second \\
\hline
\end{tabular}


the acute toxicity test was not conducted here because it has been documented (17). The plant material used in this study was collected from the same environment as the previous investigators; thus the repeat of the acute toxicity test was not necessary $(18,20)$.

The formalin- and egg-albumin induced paw edema were used as the inflammatory models while acetic acid-induced writhing and tail flick test were used as the analgesic models (21). The HAE exhibited its optimum pharmacological activities at $300 \mathrm{mg} / \mathrm{kg}$ (Tables 1, 2, 3 and 4) as an increase in dose beyond $300 \mathrm{mg} / \mathrm{kg}$ did not produce any appreciable increase in the magnitude of the activities. This might be due to receptor site saturation and inhibition (16). The HAE is a mixture of bioactive compounds that may have diverse pharmacological activities (12).

The mechanism of the analgesic and anti-inflammatory activities may be the inhibition of cyclooxygenase (COX) activity; same mechanism of ASA. ASA irreversibly inhibit the cyclooxygenase which catalyze prostaglandin production from arachidonic acid (22-24). Prostaglandins are pro-inflammatory mediators $(25,26)$. The production of prostaglandins are controlled by the level of COX(s) activity and also influenced by the relative cell-specific expression of the terminal synthases, some of which may be co-induced with COX-2 $(27,28)$.

The HAE demonstrated analgesic activity against both central and peripheral pain. The acetic acid-induced writhing is sensitive and useful in the screening of centrally and peripherally acting drugs while the tail flick test is used in the screening of centrally acting drugs (20). Another possible mechanism of the analgesic activity may be desensitization of the nociceptor and/or increase in the pain threshold in the hypothalamus (22).

In conclusion, the study affirms the folkloric uses of Helianthus annuus in the management of pain and inflammation. Further study is desired to isolate and characterize the active principle(s).

\section{Abbreviations}

ASA: acetylsalicylic acid

LSD: Least Significant Difference

SEM: standard error of mean

ANOVA: one way analysis of variance

HAE: Helianthus annuus extract

COX: cyclooxygenase

\section{Acknowledgment}

We acknowledge the contribution of Mr A. O. Ozioko in the identification of the plant sample.

\section{Conflict of interest statement}

The authors declare no conflict of interest

\section{References}

1. McGonagle D, McDermott MF. A proposed classification of the immunological diseases. PLoS medicine 2006; 3(8): e297.

2. Raicevic G, Najar M, Najimi M, El Taghdouini A, Van Grunsven LA, Sokal $\mathrm{E}$, et al. Influence of inflammation on the immunological pro- file of adult-derived human liver mesenchymal stromal cells and stellate cells. Cytotherapy 2015; 17(2): 174-185.

3. Heymann F, Peusquens J, Ludwig-Portugall I, Kohlhepp M, Ergen $\mathrm{C}$, Niemietz $\mathrm{P}$, et al. Liver inflammation abrogates immunological tolerance induced by Kupffer cells. Hepatology 2015; 62(1): 279-291.

4. Ajayi AM, Ologe MO, Ben-Azu B, Okhale SE, Adzu B, Ademowo OG. Ocimum gratissimum Linn. Leaf extract inhibits free radical generation and suppressed inflammation in carrageenan-induced inflammation models in rats. J Basic Clin Physiol Pharmacol 2017; 28(6): 531-41.

5. Lee HJ, Shin JS, Lee KG, Park SC, Jang YP, Nam JH, et al. Ethanol Extract of Potentilla supina Linne Suppresses LPS-induced Inflammatory Responses through NF-KB and AP-1 Inactivation in Macrophages and in Endotoxic mice. Phytother Res 2017; 31(3); 475487.

6. Shahpiri Z, Bahramsoltani R, Farzaei MH, Farzaei F, Rahimi R. Phytochemicals as future drugs for Parkinson's disease: a comprehensive review. Rev Neurosciences 2016; 27(6): 651-68.

7. Onoja SO, Udem SC, Anaga AO. Effect of chronic administration of hydromethanol leaf extract of Helianthus annuus on Erythrocytic Profile in Normal Rats. J Nutr Ther 2017; 6(2): 59-63.

8. Bashir T, Zahara K, Haider S, Tabassum S. Chemistry, pharmacology and ethnomedicinal uses of Helianthus annuus (Sunflower): A review. Pure and Applied Biology 2015; 4(2): 226-235.

9. Eze VC, Onoja SO, Ezeja MI, Eze UA. In vitro antibacterial, antioxidant and phytochemical analysis of Helianthus annuus leaves extract on some bacteria causing infection. Int J Pharm Pharm Res 2015; 4(1): 93-100

10. Onoja SO, Anaga AO. Bioassay-guided fractionation, antihyperglycemic and antioxidant properties of the methanol leaf extract of Helianthus annuus. International Journal of Pharmacognosy and Phytochemical Research 2015; 7(2): 340-346.

11. Dwivedi A, Sharma GN, Kaushik AY. Evaluation of Helianthus annuus L. leaves extract for antidiarrheal and antihistaminic activity. Int $J$ Res Ayurveda Pharm 2015; 6(1): 118-124.

12. Ogunwande IA, Flamini G, Cioni PL, Omikorede O, Azeez RA, Ayodele AA, et al. Aromatic Plants growing in Nigeria: Essential Oil Constituents of Cassia alata (Linn.) Roxb. and Helianthus annuus L. Rec NatProd 2010; 4(4): 211-217

13. Macías FA, Lopez A, Varela RM, Molinillo JM, Alves PL, Torres A. Helivypolide G. A novel dimeric bioactive sesquiterpene lactone. Tetrahedron lett 2004; 45(35): 6567-6570.

14. Ezeja MI, Omeh YN, Onoja SO, Ukaonu IH. Anti-inflammatory and antioxidant activities of the methanolic leaf extract of Cissus aralioides. Am J Pharmacol Sci 2015; 3(1): 1-6.

15. Onoja SO, Ezeja MI, Omeh YN, Onwukwe BC, Antioxidant, anti-inflammatory and antinociceptive activities of methanolic extract of Justicia secunda Vahl leaf, Alexandria J. Med. 2017; 53: 207-213.

16. Evans WC. Trease and Evans Pharmacognosy, 16th edition, Saunders Elsevier, Edinburgh, 2009; 87-89.

17. Onoja SO, Anaga AO. Evaluation of the antidiabetic and antioxidant potentials of methanolic leaf extract of Helianthus annuus L. on alloxan-induced hyperglycemic rats. Comp Clin Patho 2014; 23: 156573.

18. Carrillo W, Spindola H, Ramos M, Recio I, Carvalho JE. Anti-Inflammatory and Anti-Nociceptive Activities of Native and Modified Hen Egg White Lysozyme. J Med Food 2016; 19(10): 978-82.

19. Krishnaraju AV, Rao $C B$, Sundararaju $D$, Sengupta $K$, Trimurtulu G. Anti-inflammatory activity of Vitex leucoxylon L. bark extracts against Freund's complete adjuvant induced arthritis in Sprague Dawley rat. Am J Infect Dis 2009; 5: 68-73.

20. Sofowora EA. Medicinal plants and traditional medicine in Africa. 3rd ed. Nigeria: Spectrum books Ltd. 2008.

21. Vogel HG. Editor. Drug discovery and evaluation: Pharmacological assays. 2nd ed. Berlin: Springer; 2002 
22. Rang HP, Dale MM, Ritter JM, Moore RK. Pharmacology. 6th Edition. Edinburgh: Elsevier Churchill Livingstone. 2009.

23. Rashidian A, Mehrzadi S, Ghannadi AR, Mahzooni P, Sadr S, Minaiyan $M$. Protective effect of ginger volatile oil against acetic acid-induced colitis in rats: a light microscopic evaluation. $J$ Integr Med 2014; 12(2): 115-20.

24. Shelmadine BD, Bowden RG, Moreillon JJ, Cooke MB, Yang P, Deike $\mathrm{E}$, et al. A Pilot Study to Examine the Effects of an Anti-inflammatory Supplement on Eicosanoid Derivatives in Patients with Chronic Kidney Disease. J Altern Complement Med 2017; 23(8): 632-8.

25. Ahmad SF, Attia SM, Bakheet SA, Zoheir KM, Ansari MA, Korashy $\mathrm{HM}$, et al. Naringin attenuates the development of carrageenan-induced acute lung inflammation through inhibition of NF-kb, STAT3 and pro-inflammatory mediators and enhancement of $\mathrm{IKBa}$ and anti-inflammatory cytokines. Inflammation 2015; 38(2): 846-57.

26. Yang EJ, Hyun KH, Kim H, Kim MJ, Lee NH, Hyun CG. Acanthopanax koreanum roots inhibit the expression of pro-inflammatory cytokines, inducible nitric oxide synthase, and cyclooxygenase-2 in RAW 264.7 macrophages. Orient J Chem 2016; 32(1): 29-35.

27. Murakami M, Kudo I. Recent advances in molecular biology and physiology of the prostaglandin $\mathrm{E}_{2}$-biosynthetic pathway. Prog Lipid Res 2004; 43: 3-35.

28. Wheeler-Jones CPD, Farrar C, Garonna E. Protease-activated receptors, cyclo-oxygenases and pro-angiogenic signalling in endothelial cells. Biochem Soc Trans 2009; 37: 1179-83. 